\title{
The Rohingya Refugee Crisis: Legal Protection on International Law and Islamic Law
}

\author{
M. Alvi Syahrin \\ Student at Doctoral Program of Law, Faculty of Law, Universitas Borobudur, Jakarta, Indonesia \\ Email: ma.syahrin@gmail.com
}

\begin{abstract}
The news relating to Myanmar Rohingya minority refugees attracted international attention, after hundreds of boatmen fled Myanmar and were stranded in Aceh. According to the United Nations report until December 2017, the number of Rohingya refugees reached 515,000. The number is increasing considering the conflict in Myanmar has not been resolved. In this article will examine how the protection of Rohingya refugees in the perspective of international law and Islamic law. The research method used in this paper is qualitative normative legal research method with deductive logical thinking. Based on research, it can conclude that refugee protection under international law is regulated in the 1951 Convention and 1967 Protocol governing the principles and rights and obligations of refugees. According to Islamic law refugee protection is contained in the QS. Al Hasyr: 9 which contains the principles and rights of asylum seekers. Whether in international law or Islamic law, the principle applied to refugees is a nonrefoulment principle. This principle has become an international customary law so it must be implemented by all countries.
\end{abstract}

Keywords-Rohingya, Refugees, International Law, Islamic Law

\section{INTRODUCTION}

The problem of refugees and displacement of people in the country is the most complicated issue facing the world community today. Many discussions that take place in the United Nations that continue to seek more effective ways to protect and assist these particularly vulnerable groups (Santoso, 2014: 4). A number of people calling for promised increased cooperation and coordination between the institutions of the giver of aid, others point to gaps in international regulations and urge forward the standard in this field further. However everyone agrees that this issue is a matter of multidimensional and globally. Thus any approach and the way out should be done comprehensively and explain all aspects of the issue of the causes of mass exodus to a response outlining the need for tackling the problem of refugees range from a State the emergency until their repatriation (Havid, 2004: 88).

Currently, refugee protection is still a reason for the existence of the United Nations of High Commission for Refugees (UNHCR). UNHCR had a responsibility to give protection to refugees (Betts, 2010: 210). Based on Global Trends 2011 report expressed by UNHCR on June 18, 2012, showed 3.5 million people displaced from their homes but remain inside the country. Officials of UNHCR, Antonio Guterres said the world body was grateful for the international system that protects refugees served well and poultice-border remains open. According to the United Nations, by the end of 2011 , there is 47.5 million as refugees, displaced persons or asylum seekers. Afghanistan is the largest producer of refugees that is 2.7 million, followed by Iraq, Somalia, Sudan and Congo (Syahrin, 2015: 14).

In General, the evacuation was done due to the suppression of the rights of refugees in their countries. In General, they are also looking for land or other countries as his new residence which is certainly far from the
Suppression of human rights. Search new country by refugees of course should be regarded as a basic human right (Syahrin, 2016: 7).

A refugee is a person who was forced to cut ties with his native country because of fear based and experiencing oppression (persecution). The fear that this is what distinguishes based refugee with other types of migrants, any weighing the situation, and also of others who are in need of humanitarian assistance. Refugees cannot rely on the protection of the country that is supposed to give protection to them, then to respond to the sad situation faced by refugees, special preparation must be made by the international community.

Every country has a general duty to provide international protection as a liability which is based on international law, including international human rights law and international custom law (Kusumaatmadja, 2013: 76). So the countries that became the participants of the Convention of 1951 on the Status of Refugees and/or 1967 Protocol have obligations as stated in the legal devices that are set in the 1951 (Syahrin, 2015: 20). In practice, many countries which then handle the refugees are not in accordance with international standards that were already provided for in the Convention of 1951 and the 1967 Protocol even violate the principle regarding the prohibition of expulsion or return (non-refoulement) who has become an international customs law.

Related to the protection of foreign nationals particularly the refugees, in addition to regulated in international law, Islamic law has long been set concerning the protection of human rights. Islamic law is affecting the international refugee law setting. Islamic jurisprudence is present to establish the principles of humanity, such as brotherhood, equality and tolerance. The granting of aid, guarantees of security and protection to those in need, until to the enemy though, is the noble teachings of Islamic jurisprudence, which preceded the present birth a number of 
modern international legal instruments on human rights and refugees, which regulates, among other things, the right of asylum and extradition ban on refugees. It's all in order to protect the safety of the soul of the person concerned and prevents it from persecution or murder (Abu Wafa', 2011: 10)

Islamic law set up in Article 12 of the Charter of the Universal Declaration of Human Rights according to Islam which States, "Everyone has the right, in the view of Islamic jurisprudence, travel and fled to another country ... in the face of persecution". The destination country is obligated to provide asylum to such persons so that he obtained a security exception breakout driven by reasons and actions that are seen by the Islamic jurisprudence as a crime.

Based on reports from UNHCR, stated that at the end of the year 2015 the number of people who make the shift was forced to reach 65.3 million people, whereas in previous years the number of records as much as 59.5 million people. This is the first time 60 million limit exceeded. There are some countries that are more prominent, i.e. Syria with 4.9 million, with 2.7 million, Afghanistan and Somalia with 1.1 million, the three countries together accounted for more than half of the refugees under UNHCR's mandate throughout the world. The majority of refugees are currently dominated by muslim countries. In addition also occurs in Bangladesh and Myanmar. But unfortunately, the spirit of universal human rights protection turns out to be not his full can be feel by the muslims in the world. One of them is from the country of Rohingya asylum seekers Myanmar.

Preaching minority Rohingya refugee related tribes of Myanmar to invite the attention of the international community, after hundreds of boat people fleeing from Myanmar and stranded in Aceh. They reveal the mistreatment received during your stay in Thailand. In early January 2009, the Navy of Thailand Rohingya boat people has caught in the waters of the Andaman and then forced about 1000 boat people back out to sea in boats without engines and without supplies of water and food adequate (Rismayanti, 2009: 16).

The Muslim Rohingya is ethnic muslim who inhabit the country of Burma (Myanmar). In addition to the Rohingya Muslims, there are still some other muslim ethnic group living in Myanmar. It was very unfortunate for muslim Rohingya were never included in the list of 137 ethnic recognized by the Government of Myanmar. The absence of this recognition led to their have not citizenship. The condition is not clear legally making the Government of Myanmar Rohingya Muslims are treated inhumanely. Most of the Rohingya Muslims get the ordeal of the military junta of Myanmar, even some of them have become victims of human trafficking. Weighing the exam they receive in the country of his birth, forcing the muslim Rohingya to come out of Myanmar and live as boat people (Allain, 2002: 538).

Observe the legal events, then this article is meant to explain about setting protection against refugees according to international law and Islamic law as well as a form of protection against the Rohingya boat people according to law international and Islamic law.

\section{RESEARCH METHOD}

\section{A. Method Approach}

The formulation of the problem shows that the research is done by approach of normative juridicial approach, where the normative jurisdiction is to examine a legal problem and make the settlement through the applicable legislation.

\section{B. Research Spesifications}

The spesification of this study is descriptive analysis to provide an overview of the real facts along with an accurate analysis of laws and regulations that can be used as material analysis related to abuse of dominant position.

\section{RESULT AND DISCUSSIONS}

\section{A. Legal Protection of Rohingya Refugees on International Law}

Rohingya have occupied two towns in Northern Rakhine State, formerly known as the Western region of Arakan, Burma since the 7th century AD. Currently, there are about 600,000 people Rohignya who lives in Myanmar. For years they got bad and discriminatory treatment from the Government of Myanmar.

According to UNHCR, there are currently about twenty eight thousand Rohingya people living in refugee camps in Bangladesh. Ironically the muslim Rohingya ethnic not recognised by either Myanmar or Bangladesh as its citizens so that it can be said that Rohingya is stateless.

Rohingya's freedom severely curtailed, majority of their citizenship are not recognized. They have not even granted the right of ownership over the land and work on a number of infrastructure development work in Myanmar. Such discrimination has been forcing them to become a boat people and leave myanmar to find safety and a better livelihood in other countries. The countries that becomne their destination and transit are Bangladesh, Malaysia, Pakistan, Saudi Arabia, Thailand, Indonesia and Singapore.

How is the status of Rohingya boat people? Tracing the sense above, they are people without a nationality (stateless persons) and asylum seekers. But it is unclear whether then a nation will give them status as a refugees or not. There are some facts related Rohingya boat people. First, Rohingya is not recognized as the people of Myanmar (stateless); Second, they experience discrimination and racist whether economic, social or political; and Third, the ethnic Rohingya suffered various torture and human rights violations with given the minimal wage and without even being given the wages in various infrastructure development projects in Myanmar (Handayani, 2002: 158).

Rohingya has experienced a wide range of pressure and its treatment discrimination as stated in Article 1 of the 1951 Convention which mentions regarding the definition of a refugee is a person who is outside the country of origin or residence, experiencing fear of prosecution due to race, religion, nationality, membership in a particular social group or have a different political view, and has no nationality and unable or unwilling to obtain protection from their country due to these fears. Based on the provisions of the Convention, the Rohingya boat people entitled to refugee 
status.

The refugees became an international problem. The protection arrangement of refugees is a general principle of human rights (Syahrin, 2015: 11). According to Article 14 of the Charter of the Universal Declaration of Human Rights, "Everyone has the right to seek and to enjoy asylum in other countries to protect him from persecution/torture. The 1951 Convention as a regulation that protects and provides assistance on refugees. There are some protection which is given by the convention (Suwardi, 2004: 35).

First, there is no discrimination. States parties to the convention should not be treated as refugees based on good political discrimination with regard to race, religion or country of origin or skin color and they have the freedom to exercise their religion (Article 3 and 4).

Second, the personal status of the refugees is governed according to the laws where they are domiciled. If they do not have their personal status, domicile is governed by the law in which they are placed (place of residence). Rights relating to marriage should also be recognized by the signatories and of the Protocol (Article 12). Third, a refugee has the same rights in regard to property rights or have had a good move or not move and save it as much as others and can also be transfer their assetto the country where he will settle (Article 13,14 and 30). Fourth, signatories should recognize the freedom of refugees to associated with setting up the Assembly including a bevy of trade along the Assembly it is non-profit and non-political (Article 15). The provisions ini is the right of Assembly. Fifth, a refugee would have had the freedom to litigants in front of the judiciary (Article 16). Sixth, reserves the right to get a job and set up a trading company and other free work, where this free work must comply with the provisions that have been recognized, such as signs the certificate, the point is to know expertise to be placed on a suitable job (Article 17, 18 and 19). Seventh, each refugee will receive equal treatment with the nationals of the other over the right of acquiring education primary school (Article 22). Eighth, each of the refugees will be able to enjoy the right to social welfare, such as the rights to work, housing, getting wages from a work that their does (Article 20 and 22). This is an entitlement to social welfare. Ninth, each refugee is entitled to letters and identity travel document to outside of the territory of the country where he placed except for reasons of security and public interest. The travel documents issued on international agreements will be recognized by the signatories (Article 27 and 28).

Apart from the rights of refugees who named the above program, the convention sets out obligations has also been stated in Article 2 of the Convention:

"Every refugee has duties to the country in which he finds himself, which require in particular that he conform to its laws and regulations as well as to measures taken for the maintenance of public order."

Based on Article 2, each refugee is obliged to comply with all applicable laws and regulations for creating public order in the country in which he is placed.

Based on Article 14 (1) of the Universal Declaration of Human Rights 1948, everyone has the right to seek and to enjoy asylum from other countries because of fear of torture.
The right to seek asylum contains notions that people fleeing from persecution and to enter the territory of another country without bringing a complete document must be given permission entry to a country, at least for a temporary period of time (Syahrin, 2014: 25). Every asylum seeker have the right not to be expelled or forcibly returned when they had arrived in a country with an uncommon way. This is known as the principle of non-refoulement (Syahrin, 2018: 43-57). The non-refoulment principle should be distinguished from expulsion or deportation or expulsion. The deportation is carried out if foreign nationals do actions that are against the law in the country of the recipient or it is the offender who escaped from court proceedings, whereas the non-refoulment principle used only against refugees or asylum seekers (Riyanto, 2010: 697).

Article 33 (1) of the 1951 Convention states that the state parties to this convention are not allowed to expel or return a refugee in any form outside the territory where their safety and freedom threatened for reasons of race, religion, nationality, membership in a social group or political opinion.

The non-refoulment principle is not only found in the 1951 Convention, but also listed implicitly or explicitly on Article 3 Against Torture Convention, Article 45 paragraphs 4 IV Geneva Convention, Article 13 International Covenant on Civil and Political Rights and other human rights instruments. This principle has been recognized as part of international customs. In a sense, the country has yet to become a party to the 1951 Convention have to respect the non-refoulment principle (Syahrin, 2017: 168-178).

Both Myanmar, Thailand, and Indonesia have not yet become states parties (state parties) of the 1951 Convention. However those countries unable to relinquish his responsibilities for granted against Rohingya. The Thailand Government actions who catch and throw Rohingya has violated the provisions of the convention.

Myanmar as the country of origin is the most responsible for dozens of years of Rohingya. Myanmar also let the occurrence of torture and discrimination against them on the basis of ethnic and religion (persecution). The things which can be classified as a crime of the state.

Thailand and Indonesia were responsible for not immediately expelled and forcibly return them (nonrefoulement) when the origin of the Rohingya stranded or arrive in the territory of its sovereignty through the unorthodox way. The best way is to accommodate them temporarily while determining the next process, whether to give asylum straight, forward to another country, or return to the country of origin when conditions are indeed possible (Nasution, 2016: 12).

The decision of Indonesia Government hold while Rohingya asylum seekers are things that should be done from the side of international law. The Indonesia Government indeed may not give the status of refugees (refugee) to them because it considers them coming because economic motives, but not necessarily be cast out and give temporary shelter is they should have been carried out according the non-refoulement principle in the 1951 Convention. 


\section{B. Legal Protection of Rohingya Refugees on Islamic Law}

1. Human Rights Protection on Islam

Refugee protection is related to the protection of human rights ingGeneral. In Islam there are two words that are often translated as Islamic law i.e. Sharia and fiqh. Sharia is the word of Allah and the Sunnah. So the main sources of the Qur'an and the sharia is Sunnah. While fiqh is ijtihad a human over sharia law which consists of the Qur'an and Sunnah (Hasanah, 2010: 718).

Human rights in Islam, not only recognized but is fully protected as one of the pillars of Islamic buildings. This principle has outlined in the Qur'an, among others, in Al-Isra verse 70:

"And indeed We exalt the sons of Adam, we carried them on land and in the ocean, we give them a sustenance from the good things and we debate them with the advantages of most creatures that we have created."

The verse expressed human glories in the text of the Qur'an called the karamah (glory). Mohammad Hasbi Ash Shiddieqy karamah divides into three categorizes. First, personal glory or karomah fardiyah; second, the glory of the society or karomah ijtimaiyah; and third, glory or political karomah siyasiyah. In the first category, human beings are protected both personal as well as his wealth. In the second category "status is fully guaranteed the human equation" and in the third category, Islam fully guarantees political rights of his people.

On the date of August 5, 1990, Islamic countries grouped in the Organization of the Islamic Conference produce a humanitarian declaration according to the Islamic law based on the Qur'an and Sunnah. The Declaration called the Cairo Declaration consists of 25 chapters. The Declaration state that all rights and freedom are subject to Sharia or Islamic law. These rights include: the right to life (QS. Al-Isra: 33, Al-An'aam: 151); the right to equality and status by (QS Al Baqara: 286); freedom of expression (QS. At-Tawba: 71); the right of freedom of religion (QS. AlBaqara: 256); property rights (QS. Al-Baqara: 188, AnNisaa: 29); rights get justice (QS. Ash-Shu'araa Council: 15); rights to get the basic necessities of human life (QS. Adz-Dzariyat: 19); and get an education (QS. Yunus: 101).

With regard to asylum seekers, in order to be granted asylum in accordance with the provisions of the Islamic shari'a then must be met some of the requirements. First, the asylum seekers are in Islamic countries or in regions that are subject to the Islamic state. This makes sense, because to be given asylum by an Islamic country, asylum seekers must reside in the territory of the Islamic state that. The term "Islamic countries" includes areas where sharia is applied, and the people who inhabit it, whether muslim, non-muslim (dzimmiy) to any other person, is under the protection of Islam and be protected on the basis of the teachings of Islam. In this regard, Abu Haniffah suggests three (3) terms of what is known as the Islamic state (Dâr al-Islâm), that the rules are enforced sourced from Islamic jurisprudence; countries that were neighbours with other Islamic countries; and its inhabitants, whether muslim or non-muslim, are protected on the basis of the teachings of Islam. So is the case, the asylum/protection can be provided, as we will discuss further, in the territories that are subject to the Islamic countries (such as the diplomatic mission places or warships).

The jurisprudence also recognizes asylum/protection provided in other countries, and is in line with the application of the principle of jurisdiction the territorial principle of jurisdiction and a non-Islamic country's territorial expansion into territory that is not part of the Islamic state. Second, there are a motive for acquiring asylum and in the eyes of Islam, all the motives that are equivalent.

\section{The Asylum Acquiring Principles in the Qur'an}

Q.S. Al-Hashr: 9 setting the five main principles of asylum and treatment of refugees. Allah state that:

"And people who have short-lived in the city of Medina and believe (ansâr) before (the coming of) their (muhâjirîn), (ansâr) loving people who migrated to them (muhâjirîn). And they (ansâr) there is no put the desire in their hearts against anything given to them (muhâjirîn); and they give priority to (people of emigrants), upon themselves."

From this verse clearly visible a few principles. First, a muslim should be pleased and excited to welcome refugees (or immigrants from a region to another region) and get along well with them. Allah state that:

"... they (ansâr) loving people who migrated to them (muhâjirîn) ...". Therefore, the asylum seekers should not be expelled to the outside boundary of the territory of the Islamic state or a rejected return."

Second, muslims should treat them well, and to prioritize the interests/needs of their lives. This is evident from Allah, "... and they give priority to (people of emigrants), on behalf of themselves ...". The meaning of al$\hat{\imath} t s a ̂ r$ is more emphasis on others instead of himself about the needs/interests of the mundane foolishness and wants the ukhrawi advantage. This attitude was born from a strong confident stance, the love of Allah, and patience against the difficulties. Such is the case, because other people prefer the attitude in the Affairs of life are above other people prefer the attitude in the affairs of property even if the return to the Affairs of life as well.

Third, sympathetic acceptance against the refugees, whether rich or poor. This is evident from Allah:

"And they (ansâr) there is no put the desire in their hearts against anything given to them (muhâjirîn) ...".

Thus, whether the refugees were rich or poor people don't have any influence, since this problem only with regard to protective measures and guarantees the security and welfare of refugees in the area of self against/destination countries.

Fourth, there is not to refusing even the inhabitants of the immigrant/migration destination country the immigrant was middle of crisis, poverty and increased living needs. This is evident from Allah, "even if they're in trouble ...", i.e. the poverty the urgent necessities of life or at least treasures.

Fifth, this verse also proves the existence of a territorial 
asylum, this is reflected in the verse, "and the people who have lived in the city of Medina and believe (ansâr) before (the coming of) their (muhâjirîn) ...". That is to say, those who live in the country and make it as the ground of their residence. This shows that the population of dae-rah/region mandatory migration destinations receive the arrival of immigrants to the region/country of them.

The condition of the Rohingya immediately invites attention to a lot of parties, from the Islamic world. This can be understandably, because Islam is a system of perfect life and thorough. Islam covers all aspects of life, so that Islam also give attention to the protection of human rights and uphold the principle of the equation. Acts of persecution that has been conducted against the Rohingya are clearly not justifiable and contrary to Islamic teachings. The fate of the Rohingya demanded the sympathy of muslims in the world, especially in Indonesia.

There are at least four main reasons that can be used as a foothold for muslims to treat Rohingya.

First, the Islamic ummah solidarity. One of the main principle in Islam is the principle building ukhuwah / fraternity. Allah said in surat Al-Hujarat verse 13:

"O man, verily, We created you from a male and a female, and made you from various nations that you may know each. Verily, the most glorious of you is the most Allah-fearing among you. Verily, Allâh is all-Knowing Supreme again to know. "

Based on the above, it can be taken a lesson that the relationship between people is basically peace. This paragraph also explains a few other things, namely: (a) the origin of mankind is one. It is similar with the previous paragraph which states that every muslim is brothers; (b) Allah made humans from various nations in order to know each other with a view to mutually agreed upon as a basis in the relationship between individuals and groups; (c) determine the size of a human quality, i.e. committed; (d) comprehensive statements in this paragraph to all mankind, not only to those who believe.

This verse has called for the people to safeguard world peace in general. Abuse and torture against one specific ethnicity obviously contrary to this clause, especially if it turns out that people who are persecuted are those muslims who are cautious. Whereas those who believe it is the brothers and defense of fellow muslims is a thing worth fighting as the complete faith of the muslims.

Second, Maqasid Al Shariah Khamsah. Accodring to the Ash Syatibi, everything in the world is definitely has a purpose, as well as with the Islamic jurisprudence. This theory is commonly referred to with the Maqasid Al Shariah Khamsah or five purposes of Islamic law. The fifth objective of this jurisprudence are: protection against religion, soul, intellect, lineage and property. In the case of the Rohingya, the treatment of Milter junta Myanmar and Thailand Governments was opposed to the Maqasid Sharia. The entire primary human needs protection to survive has been violated. Protection of religion could not be felt by Rohingya. According to the information in several media, Myanmar's military Junta has tortured Rohingya who ultimately forced them to get out of the place itself. The Rohingya live in the boat away from the life he deserves.
Then this case has broken at least three of the five purposes of the Islamic jurisprudence.

Human rights in Islam is not only recognized, but is fully protected as one of the pillars of Islamic buildings. This principle is expressly outlined in the Qur'an, among others, in surah $\mathrm{Al}$ Isra verse 70:

"And indeed We exalt the sons of Adam, we carried them on land and at sea, We give them a sustenance from the good things and we debate them with the advantages of most creatures that we have created."

That verse expressed human glories in the text of the Qur'an called the karamah (glory). Mohammad Hasbi Ash Shiddieqy divides karamah into three categorizes i.e. personal glory or karomah fardiyah; the glory of the society or karomah ijtimaiyah; and glory or political karomah siyasiyah. In the first category, human beings are protected both personal as well as his wealth. In the second category status is fully guaranteed the human equation and in the third category, Islam fully guarantees political rights of his people.

In the case of the Rohingya, personal glory as a man who becomes independent has been omitted by the existence of torture and human trafficking. Glory as a human entity in a tribe, ethnic group, or any name that has the right to do is treated equally before the law has been violated. Not the presence of the Rohingya ethnic recognition of the cause they have no citizenship had violated the doctrine of human rights related to civil and political rights, which of course everyone in the world has the right to have citizenship.

Recognition of the Islamic human rights which so dominant was also poured into some of the conventions and international treaties in the world, one of them in the Cairo Declaration on Human Rights in Islam 1990. Article 1 state that:

"All human beings form one family whose members are united by submission to Allah and descent from Adam. All men are equal in terms of basic human dignity and basic obligations and responsibilities, without any discrimination on the grounds of race, colour, language, sex, religious belief, political affiliation, social status or other considerations. True faith is the guarantee for enhancing such dignity along the path to human perfection."

In addition, based on the Q.S. Al-Hashr: 9 set five main principles of asylum and related grammar handling/treatment of refugees. Allah said that:

"And people who have short-lived in the city of Medina and believe (ansâr) before (the coming of) their (muhâjirîn), (ansâr) loving people who migrated to them (muhâjirîn). And they (ansâr) there is no wanting in their hearts against anything given to them (muhâjirîn); and they give priority to (people of emigrants), upon themselves, though they also memer-badly."

From this verse clearly visible the principles below. First, the muslims should be pleased and excited to welcome refugees (or immigrants from a region to another region) and get along well with them. Therefore, the asylum seekers should not be expelled to the outside boundary of the territory of the Islamic State or a rejected return. Second, the 
muslims should treat them well, and prioritize the interests/needs of their lives. Third, sympathetic acceptance against the refugees, whether rich or poor. Fourth, there is no rejected immigrants though inhabitants of the migrants destination. Fifth, the existence of territorial asylum that is those living in the country and make it as the ground of their residence. This shows that the population of the area/region mandatory migration destinations receive the arrival of immigrants to their countries.

As a country which has a muslim majority population, Indonesia muslim should respects the principles set forth in the Holy Quran and international conventions. Thus, Indonesia muslim already treats Rohingya who were stranded in the waters of Aceh as well as respect for the protection of human rights according to international law and Islamic law.

\section{CONCLUSION}

The protection of Rohingyas according to international law is provided for in Article 33 (1) of the Convention on Refugee Status 1951 states that States Parties to the present Convention shall not be allowed to evict or return refugees of any kind outside their territory where their safety and freedom are threatened for reasons of race, religion, nationality, membership of a social group or a particular political opinion. The principle of non-refoulement is binding not only to the state party to the convention but also to all countries in the world. Then, the protection of spiritual refugees according to Islamic law is regulated in Q.S. AlHasyr: 9. The verse of the Qur'an contains the following principle. First, Muslims should be happy and happy to welcome refugees (or immigrants from one area to another). Second, Muslims should treat them well. Third, accept the presence of refugees in bai. Fourth, the ban refused immigrants even though the migration destination of immigrants was in crisis. Fifth, the existence of territorial asylum.

\section{REFERENCES}

[1] Abu Wafa', Ahmad. (2011). Hak Pencarian Suaka dalam Syariat Islam dan Hukum Internasional (Suatu kajian Perbandingan). Translated by Dr. Asmawi dkk. UNHCR.

[2] Allain, Jean. (2002). The Jus Cogens Nature of Non Refoulment, International Journal of Refugee Law, 538.

[3] Betts, Alexander. (2010). Towards a soft Law Framework for the Protection of Vunarable Irregular Migrants. International Journal of Refugee Law, 210.

[4] Handayani, Irawati. (2002). Perlindungan terhadap Pengungsi Domestik (Internally Displaced Persons) dalam Sengketa Bersenjata Internal Menurut Hukum Internasional. Jurnal Hukum InternasionaI, 158.

[5] Hasanah, Uswatun. (2010). Human Rights in The Perspective of Islamic Law. Jurnal Hukum Internasional, 718.

[6] Havid, Ajat Sudrajat. (2004). Pengungsi dalam Kerangka Kebijakan Keimigrasian Indonesia Kini dan yang akan Datang”. Jurnal Hukum Internasional, 88.

[7] Kusumaatmadja, Mochtar dan Etty R. Agoes. (2013). Pengantar Hukum Internasional. Alumni.

[8] Nasution, M. Arif. (2016). Globalisasi dan Migrasi Antar Negara. Alumni.
[9] Rismayanti, Irma D. (2009). Manusia Perahu Rohingya: Tantangan Penegakan HAM di ASEAN. Opinio Juris, 16

[10] Riyanto, Sigit. (2010). The Refoulement Principle and Its Relevance in the International Law System. Jurnal Hukum Internasional, 697.

[11] Santoso, M. Iman. (2014). Perspektif Imigrasi dalam Migrasi Manusia. Pustaka Reka Cipta.

[12] Suwardi, Sri Setianingsih. (2004). Aspek Hukum Masalah Pengungsi Internasional. Jurnal Hukum Internasional, 35.

[13] Syahrin, M. A. (2017). The Implementation of NonRefoulement Principle to the Asylum Seekers and Refugees in Indonesia. Sriwijaya Law Review, 1(2), 168-178.

[14] Syahrin, M. A. (2018). Menakar Kedaulatan Negara dalam Perspektif Keimigrasian. Jurnal Penelitian Hukum De Jure, 18(1), 43-57.

[15] Syahrin, M. Alvi. (2014). Penyadapan oleh Australia, Sebaiknya Imigrasi Bersikap. Bhumi Pura Magazine. Directorate General of Immigration.

[16] Syahrin, M. Alvi. (2015). Imigran Ilegal, Migrasi atau Ekspansi?. Check Point Magazine. Academy of Immigration.

[17] Syahrin, M. Alvi. (2015). Hak Asasi Bermigrasi. Bhumi Pura Magazine. Directorate General of Immigration.

[18] Syahrin, M. Alvi. (2016) Eksodus Warga Negara Tiongkok: Antara Kebijakan dan Penyelundupan. Check Point Magazine. Academy of Immigration.

[19] The 1948 Universal Declaration of Human Rights

[20] The 1990 Cairo Declaration of Human Rights

[21] The 1951 Refugee Convention

[22] The 1967 Refugee Protocol 